\title{
Optimalisasi Perangkingan Nilai Akademik dan Non Akademik dalam Proses Pengawasan Studi Mahasiswa Menggunakan Metode AHP
}

\author{
Rosmini $^{\#+1}$, Abdul Fadlii ${ }^{* 2}$, Sunardi $^{* 3}$ \\ ${ }^{\#}$ Magister Teknik Informatika Universitas Ahmad Dahlan, Jl. Prof. Dr. Soepomo SH, Warungboto, Umbulharjo, Kota \\ Yogyakarta \\ ${ }^{+}$Sistem Informasi STMIK PPKIA Tarakanita Rahmatika, Jl. Yos Sudarso RT. 06 No. 06, Kota Tarakan \\ ${ }^{1}$ rosminieppkia.ac.id \\ *Teknik Elektor Universitas Ahmad Dahlan, Jl. Prof. Dr. Soepomo SH, Warungboto, Umbulharjo, Kota Yogyakarta \\ ${ }^{2}$ fadlileuad.ac.id \\ ${ }^{3}$ sunardiluad.ac.id
}

\begin{abstract}
Abstrak- Proses pembelajaran mahasiswa sering kali mengalami penurunan kualitas yang dipengaruhi faktor internal maupun eksternal. Hal ini juga menjadi perhatian khusus bagi program studi. Untuk mengatasi dan menyelesaian masalah tersebut dibutuhkan sebuah sistem pendukung keputusan menggunakan metode Analytic Hierarchy Process (AHP), dengan mengotimalkan data mahasiswa untuk peningkatan kualitas pembelajaran dengan melakukan pengawasan studi. Adapun kriteria yang digunakan yaitu akademik dan non akademik. Hasil dari penelitian ini adalah bentuk perangkingan metode AHP berdasarkan nilai akademik dan non akademik, dari 20 data yang digunakan ada 8 mahasiswa yang memiliki nilai terendah, mahasiswa tersebut yang membutuhkan pengawasan secara ekstra dalam proses pembelajaran.
\end{abstract}

Kata kunci - Perangkingan, Pengawasan, Studi Mahasiswa, Nilai Akademik, AHP

\section{Pendahuluan}

Pengawasan adalah proses pengamatan dari pelaksanaan seluruh kegiatan organisasi untuk menjamin agar supaya semua pekerjaan yang sedang dilakukan berjalan sesuai dengan rencana yang telah ditentukan sebelumnya.

Proses pembelajaran mahasiswa sering kali mengalami penurunan kualitas yang dipengaruhi faktor internal maupun eksternal. Untuk menyelesaikan masalah tersebut penulis melakukan optimalisasi data mahasiswa dengan memanfaatkan metode Analytic Hierarchy Process (AHP) untuk peningkatan kualitas dengan melakukan pengawasan proses pembelajaran

Analytic Hierarchy Process (AHP) merupakan model pendukung keputusan yang dikembangkan oleh Thomas L. Saaty. Model pendukung keputusan ini menguraikan multi faktor atau multi kriteria yang kompleks menjadi suatu hirarki, menurut Saaty (1993), hirarki didefinisikan sebagai representasi permasalahan yang kompleks dalam suatu struktur multi level. Level pertama adalah tujuan, yang diikuti level faktor, kriteria, sub kriteria, dan seterusnya ke bawah hingga level terakhir dari alternatif. [1] [2]

Pada penelitian ini untuk pengambilan keputusan menggunakan metode AHP. Hasil yang harapkan dari penelitian ini adalah perangkingan mahasiswa yang membutuhkan pengawasan secara ekstra dalam proses pembelajaran.

\section{PENELITAN YANG TERKAIT}

Penelitian ini mengacu pada 5 penelitian sebelumnya. Penelitian pertama yaitu Analisa Pengawasan Studi Mahasiswa Menggunakan AHP dan Clustering K-Means sebagai Bahan Evaluasi Akademik. Penelitian ini bertujuan untuk menghasilkan informasi pengetahuan tentang mahasiswa yang perlu mendapatkan perhatian khusus berdasarkan nilai kompetensi dan kehadiran mahasiswa. [3]

Penelitian kedua yaitu AHP untuk Penentuan Rangking Penggunaan Lahan berdasarkan aspek kriteria yaitu demografi sosial, ekonomi, rencana tata ruang dan wilayah serta aspek lingkungan. [4]

Pada penelitian ketiga yaitu Analisa dan Penerapan Metode AHP dan Promethee untuk Menentukan Guru Berprestasi. Hasil dari penelitian ini dalam bentuk perangkingan berdasarkan nilai tertinggi dari proses penilaian pada penggabungan kedua metode tersebut, sehingga penggabungan kedua metode tersebut layak digunakan dalam pemelihan guru berprestasi. [5]

Penelitian keempat yaitu Sistem Pendukung Keputusan Siswa Berprestasi Menggunakan Metode 
Analytic Hierarchy Process (AHP) pada SMK Singosari Delituaa. Hasil dari penilitian ini adalah nilai bobot dari semua kriteria setiap siswa sehingga pihak sekolah dapat menentukan siswa yang berprestasi. [6]

Penelitin kelimat yaitu Pemilihan Calon Penerima Bantuan Siswa Miskin berdasarkan kriteria : Kepemilikan KPS, Kepemilikan Orang Tua, Penghasilan Orang Tua dan Prestasi Akademik. Hasil dari penelitian ini untuk membantu Tim Penyeleksi BSM dalam menentukan penerima bantuan lebih tepat sasaran. [7]

Perbedaan penelitian ini dengan penelitian - penelitian sebelumnya adalah bentuk perangkingan berdasarkan nilai akademik dan non akademik untuk melalukan proses pengawasan studi mahasiswa dengan memanfaatkan metode AHP.

\section{METODE PENELITIAN}

Berikut ini metode penilitian yang dilakukan dalam bebearapa tahap yang ditunjukkan pada gambar 1:

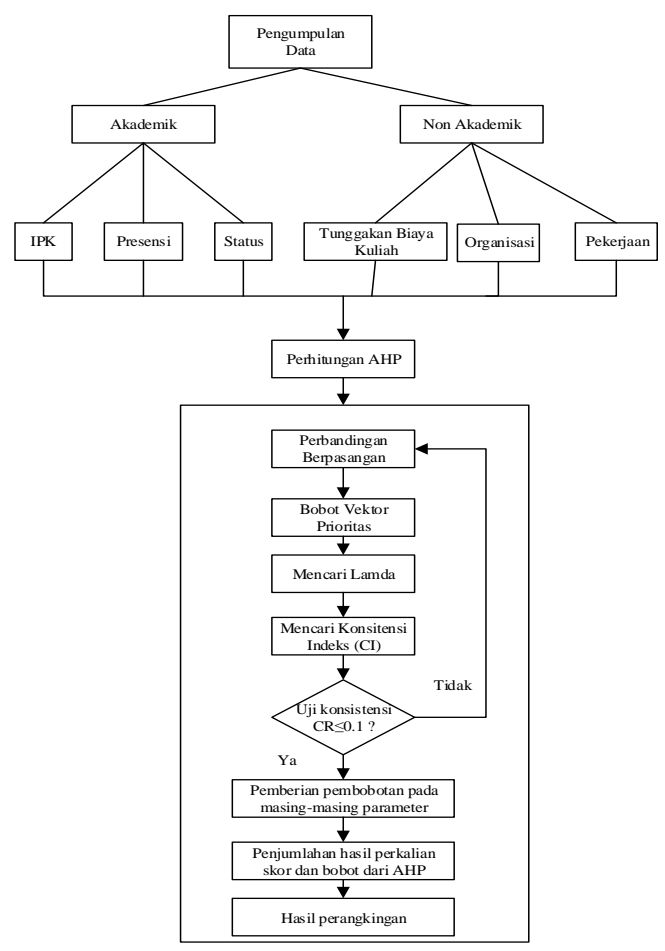

Gambar.1 Metode Penelitian

Beberapa kriteria yang digunakan untuk pengawasan studi mahasiswa sebagai berikut :

a. Akademik :

$\mathrm{C} 1=\mathrm{IPK}$

$\mathrm{C} 2=$ Presensi

$\mathrm{C} 3$ = Status

b. Non Akademik

C4 = Tunggakan Biaya Kuliah

C5 $=$ Organisasi

C6 = Pekerjaan
Sampel data manual yang digunakan sebagai berikut :

TABEL I

SAMPEL DATA MANUAL

\begin{tabular}{|c|c|c|c|c|c|c|}
\hline \multirow{2}{*}{ Mahasiswa } & \multicolumn{6}{|c|}{ Kriteria } \\
\hline & $\mathrm{C} 1$ & $\mathrm{C} 2$ & C3 & C4 & C5 & C6 \\
\hline 1 & 3,91 & 14 & A & 4.400 .000 & $\begin{array}{l}\text { Tidak } \\
\text { Aktif }\end{array}$ & $\mathrm{T}$ \\
\hline 2 & 3,06 & 14 & A & 1.537 .500 & $\begin{array}{l}\text { Tidak } \\
\text { Aktif }\end{array}$ & $\mathrm{T}$ \\
\hline 3 & 3,2 & 14 & A & 5.325 .000 & $\begin{array}{l}\text { Tidak } \\
\text { Aktif }\end{array}$ & $\mathrm{T}$ \\
\hline 4 & 3,16 & 14 & A & 1.775 .000 & $\begin{array}{l}\text { Tidak } \\
\text { Aktif }\end{array}$ & $\mathrm{T}$ \\
\hline 5 & 3,19 & 14 & A & 2.005 .000 & $\begin{array}{l}\text { Tidak } \\
\text { Aktif }\end{array}$ & $\mathrm{T}$ \\
\hline 6 & 3,08 & 13 & A & 4.050 .000 & $\begin{array}{l}\text { Tidak } \\
\text { Aktif }\end{array}$ & Y \\
\hline 7 & 3,09 & 12 & A & 2.550 .000 & $\begin{array}{l}\text { Tidak } \\
\text { Aktif }\end{array}$ & Y \\
\hline 8 & 3,27 & 14 & A & 1.775 .000 & Kurang & $\mathrm{T}$ \\
\hline 9 & 3,05 & 14 & A & 1.912 .500 & $\begin{array}{l}\text { Tidak } \\
\text { Aktif }\end{array}$ & Y \\
\hline 10 & 2,89 & 12 & TA & 2.725 .000 & $\begin{array}{l}\text { Tidak } \\
\text { Aktif }\end{array}$ & Y \\
\hline 11 & 3,38 & 14 & $\mathrm{~A}$ & 1.775 .000 & Kurang & $\mathrm{T}$ \\
\hline 12 & 3,16 & 14 & A & 3.550 .000 & $\begin{array}{l}\text { Tidak } \\
\text { Aktif }\end{array}$ & Y \\
\hline 13 & 3,02 & 12 & A & 1.775 .000 & $\begin{array}{l}\text { Tidak } \\
\text { Aktif }\end{array}$ & $\mathrm{T}$ \\
\hline 14 & 3,09 & 12 & A & 2.500 .000 & $\begin{array}{l}\text { Tidak } \\
\text { Aktif }\end{array}$ & Y \\
\hline 15 & 3,17 & 12 & A & 3.550 .000 & Aktif & $\mathrm{T}$ \\
\hline 16 & 2,91 & 11 & TA & 2.025 .000 & $\begin{array}{l}\text { Tidak } \\
\text { Aktif }\end{array}$ & Y \\
\hline 17 & 3.84 & 14 & $\mathrm{~A}$ & 1.775 .000 & $\begin{array}{l}\text { Tidak } \\
\text { Aktif }\end{array}$ & $\mathrm{T}$ \\
\hline 18 & 2,96 & 14 & $\mathrm{~A}$ & 1.775 .000 & Kurang & $\mathrm{T}$ \\
\hline 19 & 3,07 & 14 & $\mathrm{~A}$ & 1.775 .000 & Kurang & $\mathrm{T}$ \\
\hline 20 & 3,17 & 14 & A & 1.775 .000 & Kurang & $\mathrm{T}$ \\
\hline
\end{tabular}

Proses lanjutnya adalah perhitungan nilai bobot dari setiap kriteria, pertama nilai bobot dari kriteria IPK seperti pada Tabel 2

TABEL II

BOBOT IPK

\begin{tabular}{|c|c|}
\hline Parameter Ukuran & Bobot Nilai \\
\hline$<1.00$ & 1 \\
$1.01-2.00$ & 2 \\
$2.01-3.00$ & 3 \\
$3.01-3.50$ & 4 \\
$3.51-4.00$ & 5 \\
\hline
\end{tabular}

Menentukan nilai bobot dari keriteria presensi yang terdiri dari lima bilangan, seperti pada Tabel 3 
TABEL III

BOBOT PRESENSI

\begin{tabular}{|c|c|}
\hline Parameter Ukuran & Bobot Nilai \\
\hline 14 & 5 \\
13 & 4 \\
12 & 3 \\
11 & 2 \\
10 & 1 \\
\hline
\end{tabular}

Menentukan nilai bobot dari kriteria status yang terdiri dari dua bilangan, seperti pada Tabel 4

TABEL IV

BOBOT STATUS

\begin{tabular}{|c|c|}
\hline Parameter Ukuran & Bobot Nilai \\
\hline Cuti & 2 \\
Tidak Pernah Cuti & 1 \\
\hline
\end{tabular}

Menentukan nilai bobot dari kriteria tanggungan biaya kuliah yang terdiri dari lima bilangan, seperti pada Tabel 5

TABEL V

BOBOT TANGGUNGAN BIAYA KULIAH

\begin{tabular}{|c|c|}
\hline Parameter Ukuran & Bobot Nilai \\
\hline$<1.000 .00$ & 1 \\
$1.100 .000-2.000 .000$ & 2 \\
$2.100 .000-2.500 .000$ & 3 \\
$2.550 .000-3.500 .000$ & 4 \\
$>3.500 .000$ & 5 \\
\hline
\end{tabular}

Menentukan nilai bobot dari kriteria organisasi yang terdiri dari lima bilangan, seperti pada Tabel 6

TABEL VI

BOBOT ORGANISASI

\begin{tabular}{|c|c|}
\hline Parameter Ukuran & Bobot Nilai \\
\hline Sangat aktif & 5 \\
Aktif & 4 \\
Cukup & 3 \\
Kurang & 2 \\
Tidak aktif & 1 \\
\hline
\end{tabular}

Menentukan nilai bobot dari kriteria pekerjaan yang terdiri dari dua bilangan, seperti pada Tabel 7

TABEL VII

BOBOT PEKERJAAN

\begin{tabular}{|c|c|}
\hline Parameter Ukuran & Bobot Nilai \\
\hline Bekerja & 2 \\
Tidak Bekerja & 1 \\
\hline
\end{tabular}

Berikut penjelesan langkah-langkah perhitungan metode AHP sesuai pada gambar diatas, sebagai berikut :

1. Membuat matriks perbandingan kriteria dengan nilai yang telah diinputkan

2. Mencari bobot vektor prioritas dengan melakukan penjumlahan setiap kolom sel pada kolom matriks dibagi dengan jumlah kolom pada setiap selnya.

3. Mencari lamda

4. Mencari Konsitensi Index (CI)

$$
C I=\frac{\lambda m a k s-n}{\mathrm{n}-1}
$$

5. Mencari Konsistensi Rasio (CR), Tingkat konsistensi apabila nilai $\mathrm{CR} \leq 0,1$

$$
C R=\frac{C I}{R I}
$$

Setelah diperoleh CI, maka hasilnya dibandingkan dengan RI untuk setiap n objek, seperti pada Tabel 8 [1], [2], [6], [10]

TABEL VIII RANDOM CONSISTENCY INDEX (RI)

\begin{tabular}{|c|l|l|l|l|l|l|l|l|l|l|}
\hline $\mathbf{n}$ & 1 & 2 & 3 & 4 & 5 & 6 & 7 & 8 & 9 & 10 \\
\hline $\mathbf{R I}$ & 0,00 & 0,00 & 0,58 & 0,90 & 1,12 & 1,24 & 1,32 & 1,41 & 1,45 & 1,48 \\
\hline
\end{tabular}

\section{HASIL DAN PEMBAHASAN}

Nilai pada perbandingan berpasangan sesuai dengan tingkat kepentingan berikut [3], [4], [8], [9], [10]

Nilai 1 : Kedua elemen mempunyai kepentingan yang sama.

Nilai 3 : Sedikit lebih penting, pengalaman dan penilaian sangat memihak satu elemen dibandingkan dengan pasangannya.

Nilai 5: Lebih penting, satu elemen sangat disukai dan secara praktis dominasinya sangat nyata, dibandingkan dengan elemen pasangannya.

Nilai 7 : Sangat penting, satu elemen terbukti sangat disukai dan secara praktis dominasinya sangat nyata, dibandingkan dengan elemen pasangannya.

Nilai 9 : Mutlak lebih penting, Satu elemen terbukti mutlak lebih disukai dibandingkan dengan pasangannya, pada keyakinan tertinggi.

Nilai 2,4,6,8 : Nilai tengah, Diberikan bila terdapat keraguan penilaian di antara dua tingkat kepentingan yang berdekatan.

\subsection{Kriteria Akademik}

Langkah pertama pada penelitian ini membuat matrik perbandingan kriteria dengan nilai yang telah diinputkan seperti pada Tabel 9. 
TABEL IX

PERBANDINGAN BERPASANGAN AKADEMIK

\begin{tabular}{|l|c|c|c|}
\hline \multicolumn{1}{|c|}{ Akademik } & IPK & Status & Presensi \\
\hline IPK & 1 & 3 & 4 \\
\hline Status & $1 / 3$ & 1 & 2 \\
\hline Presensi & $1 / 4$ & $1 / 2$ & 1 \\
\hline
\end{tabular}

Langkah kedua mengubah nilai perbandingan berpasangan menjadi bentuk desimal dan menjumlahkan setiap kolom sel pada kolom matriks dibagi dengan jumlah kolom pada setiap selnya, seperti pada Tabel 10 .

TABEL $X$

NILAI DESIMAL

\begin{tabular}{|l|c|c|c|}
\hline \multicolumn{1}{|c|}{ Akademik } & IPK & Status & Presensi \\
\hline IPK & 1,000 & 3,000 & 4,000 \\
\hline Status & 0,333 & 1,000 & 2,000 \\
\hline Presensi & 0,250 & 0,500 & 1,000 \\
\hline Total & 1,583 & 4,500 & 7,000 \\
\hline
\end{tabular}

Selanjutnya membagi elemen tiap kolom dengan total jumlah kolom bersangkutan, seperti pada Tabel 11

TABEL XI

HASIL PEMBAGIAN NILAI ELEMEN DENGAN TOTAL JUMLAH KOLOM

\begin{tabular}{|l|c|c|c|}
\hline \multicolumn{1}{|c|}{ Akademik } & IPK & Status & Presensi \\
\hline IPK & 0,632 & 0,667 & 0,571 \\
\hline Status & 0,211 & 0,222 & 0,286 \\
\hline Presensi & 0,158 & 0,111 & 0,143 \\
\hline
\end{tabular}

Berikutnya menghitung nilai Eigen Vector Normalization (EVN) dengan cara menjumlahkan tiap baris kemudian dibagi dengen jumlah kriteria, seperti pada Tabel 12.

\begin{tabular}{|l|c|c|}
\multicolumn{3}{c}{ TABEL XII } \\
NILAI EVN \\
\hline \multicolumn{1}{|c|}{ Akademik } & Jumlah & EVN \\
\hline IPK & 1,870 & 0,623 \\
\hline Status & 0,718 & 0,239 \\
\hline Presensi & 0,412 & 0,137 \\
\hline
\end{tabular}

Langkah ketiga mencari lamda sesuai rumus yang diawali dengan perhitungan nilai eigen maksimum.

$\lambda$ maks $=(1,583 * 0,623)+(4,500 * 0,239)+(7,000 * 0,137)$

$\lambda$ maks $=3,025$

Langkah keempat menghitung konsistensi indeks (CI) dengan hasil lamda dikurang dengan banyaknya kriteria dibagi jumlah kriteria dengan rumus, sebagai berikut :

$$
C I=\frac{\lambda m a k s-n}{\mathrm{n}-1}
$$

$$
\begin{aligned}
& \mathrm{CI}=(\lambda \text { maks-n }) /(\mathrm{n}-1) \\
& \mathrm{CI}=(3,025-3) /(3-1) \\
& \mathrm{CI}=0,013
\end{aligned}
$$

Langkah kelima mencari konsistensi rasio (CR). Karena jumlah kriteria ada 3 maka nilai indeks random konsistensi (RI) adalah 0,58. Dapat dihitung dengan rumus :

$$
C R=\frac{C I}{R I}
$$

$$
\begin{aligned}
& \mathrm{CR}=\mathrm{CI} / \mathrm{RI} \\
& \mathrm{CR}=0,013 / 0,58 \\
& \mathrm{CR}=0,022
\end{aligned}
$$

Nilai CR $<0,1$ maka preferensi pembobotan adalah konsisten

\subsection{Kriteria Non Akademik}

Langkah pertama adalah membuat matrik perbandingan kriteria dengan nilai yang telah diinputkan seperti pada Tabel 13 .

TABEL XIII

PERBANDINGAN BERPASANGAN NON AKADEMIK

\begin{tabular}{|l|c|c|c|}
\hline Non Akademik & Pekerjaan & Organisasi & TBK \\
\hline Pekerjaan & 1 & 3 & 3 \\
\hline Organisasi & $1 / 3$ & 1 & 2 \\
\hline TBK & $1 / 3$ & $1 / 2$ & 1 \\
\hline
\end{tabular}

Langkah kedua mengubah nilai perbandingan berpasanga menjadi bentuk desimal dan menjumlahkan setiap kolom sel pada kolom matriks dibagi dengan jumlah kolom pada setiap selnya, seperti pada Tabel 14 .

TABEL XIV

NILAI DESIMAL

\begin{tabular}{|l|c|c|c|}
\hline Non Akademik & Pekerjaan & Organisasi & TBK \\
\hline Pekerjaan & 1,000 & 3,000 & 3,000 \\
\hline Organisasi & 0,333 & 1,000 & 2,000 \\
\hline TBK & 0,333 & 0,500 & 1,000 \\
\hline Total & 1,667 & 4,500 & 6,000 \\
\hline
\end{tabular}

Selanjutnya membagi elemen tiap kolom dengan total jumlah kolom bersangkutan, dapat dilihat pada Tabel 15 .

TABEL XV

HASIL PEMBAGIAN NILAI ELEMENT DENGAN TOTAL JUMLAH KOLOM

\begin{tabular}{|l|c|c|c|}
\hline Non Akademik & Pekerjaan & Organisasi & TBK \\
\hline Pekerjaan & 0,600 & 0,667 & 0,500 \\
\hline Organisasi & 0,200 & 0,222 & 0,333 \\
\hline TBK & 0,200 & 0,111 & 0,167 \\
\hline
\end{tabular}


Berikutnya menghitung nilai Eigen Vector Normalization (EVN) dengan cara menjumlahkan tiap baris kemudian dibagi dengen jumlah kriteria seperti pada Tabel 16.

\begin{tabular}{|l|c|c|}
\multicolumn{3}{c}{ TABEL XVI } \\
NILAI EVN \\
\hline Non Akademik & Jumlah & EVN \\
\hline Pekerjaan & 1,767 & 0,589 \\
\hline Organisasi & 0,756 & 0,252 \\
\hline TBK & 0,478 & 0,159 \\
\hline
\end{tabular}

Langkah ketiga mencari lamda sesuai rumus yang diawali dengan perhitungan nilai eigen maksimum

$\lambda$ maks $=(1,667 * 0,589)+(1,833 * 0,252)+(6,000 * 0,159)$

$\lambda$ maks $=3,070$

Langkah keempat menghitung konsistensi indeks (CI) dengan hasil lamda dikurang dengan banyaknya kriteria dibagi jumlah kriteria dengan rumus, sebagai berikut

$C I=\frac{\lambda m a k s-n}{\mathrm{n}-1}$

$\mathrm{CI}=(\lambda$ maks-n) $/(\mathrm{n}-1)$

$\mathrm{CI}=(3,070-3) /(3-1)$

$\mathrm{CI}=0,035$

Langkah kelima mencari konsistensi rasio (CR). Karena jumlah kriteria ada 3 maka nilai indeks random konsistensi (RI) adalah 0,58. Dapat dihitung dengan rumus :

$$
C R=\frac{C I}{R I}
$$

$\mathrm{CR}=\mathrm{CI} / \mathrm{RI}$

$\mathrm{CR}=0,035 / 0,58$

$\mathrm{CR}=0,061$

Nilai CR $<0,1$ maka preferensi pembobotan adalah konsisten

\subsection{Sub Kriteria Akademik}

Langkah pertama adalah membuat matrik perbandingan kriteria dengan nilai yang telah diinputkan seperti pada Tabel 17.

TABEL XVII

PERBANDINGAN BERPASANGAN SUB KRITERIA AKADEMIK

\begin{tabular}{|c|c|c|c|c|c|}
\hline Sub & 5 & 4 & 3 & 2 & 1 \\
\hline 5 & 1 & 3 & 5 & 7 & 9 \\
\hline 4 & $1 / 3$ & 1 & 5 & 7 & 9 \\
\hline 3 & $1 / 5$ & $1 / 5$ & 1 & 5 & 7 \\
\hline 2 & $1 / 7$ & $1 / 7$ & $1 / 7$ & 1 & 7 \\
\hline 1 & $1 / 9$ & $1 / 9$ & $1 / 7$ & $1 / 7$ & 1 \\
\hline
\end{tabular}

Langkah kedua mengubah nilai perbandingan berpasangan menjadi bentuk desimal dan menjumlahkan setiap kolom sel pada kolom matriks dibagi dengan jumlah kolom pada setiap selnya, seperti pada Tabel 18

TABEL XVIII

\begin{tabular}{|c|c|c|c|c|c|}
\hline Sub & 5 & 4 & 3 & 2 & 1 \\
\hline 5 & 1,000 & 3,000 & 5,000 & 7,000 & 9,000 \\
\hline 4 & 0,333 & 1,000 & 5,000 & 7,000 & 9,000 \\
\hline 3 & 0,200 & 0,200 & 1,000 & 5,000 & 7,000 \\
\hline 2 & 0,143 & 0,143 & 0,143 & 1,000 & 7,000 \\
\hline 1 & 0,111 & 0,111 & 0,143 & 0,143 & 1,000 \\
\hline Total & 1,787 & 4,454 & 11,286 & 20,143 & 33,000 \\
\hline
\end{tabular}

Selanjutnya membagi elemen tiap kolom dengan total jumlah kolom bersangkutan, seperti pada Tabel 19.

TABEL XIX

HASIL PEMBAGIAN NILAI ELEMENT DENGAN TOTAL JUMLAH KOLOM

\begin{tabular}{|c|c|c|c|c|c|}
\hline Sub & 5 & 4 & 3 & 2 & 1 \\
\hline 5 & 0,560 & 0,674 & 0,443 & 0,348 & 0,273 \\
\hline 4 & 0,187 & 0,225 & 0,443 & 0,348 & 0,273 \\
\hline 3 & 0,112 & 0,045 & 0,089 & 0,248 & 0,212 \\
\hline 2 & 0,080 & 0,032 & 0,013 & 0,050 & 0,212 \\
\hline 1 & 0,062 & 0,025 & 0,013 & 0,007 & 0,030 \\
\hline
\end{tabular}

Berikutnya menghitung nilai Eigen Vector Normalization (EVN) dengan cara menjumlahkan tiap baris kemudian dibagi dengen jumlah kriteria, seperti pada Tabel 20.

TABEL XX

NILAI EVN

\begin{tabular}{|c|c|c|}
\hline Sub & Jumlah & EVN \\
\hline 5 & 2,296 & 0,459 \\
\hline 4 & 1,474 & 0,295 \\
\hline 3 & 0,706 & 0,141 \\
\hline 2 & 0,386 & 0,077 \\
\hline 1 & 0,137 & 0,027 \\
\hline
\end{tabular}

Langkah ketiga mencari lamda sesuai rumus yang diawali dengan perhitungan nilai eigen maksimum.:

$\lambda$ maks $=(1,787 * 0,459)+(4,454 * 0,295)+(11,286 * 0,141)$ $+(20,143 * 0,077)+(33,000 * 0,27)$

$\lambda$ maks $=6,189$

Langkah keempat menghitung konsistensi indeks (CI) dengan hasil lamda dikurang dengan banyaknya kriteria dibagi jumlah kriteria dengan rumus, sebagai berikut:

$C I=\frac{\lambda m a k s-n}{\mathrm{n}-1}$ 


$$
\begin{aligned}
& \mathrm{CI}=(\lambda \text { maks-n }) /(\mathrm{n}-1) \\
& \mathrm{CI}=(6,189-5) /(5-1) \\
& \mathrm{CI}=0,297
\end{aligned}
$$

Langkah kelima mencari konsistensi rasio (CR). Karena jumlah kriteria ada 5 maka nilai indeks random konsistensi (RI) adalah 1,12. Dapat dihitung dengan rumus:

$$
C R=\frac{C I}{R I}
$$

$\mathrm{CR}=\mathrm{CI} / \mathrm{RI}$

$\mathrm{CR}=0,297 / 1,12$

$\mathrm{CR}=0,003$

Nilai CR $<0,1$ maka preferensi pembobotan adalah konsisten

Nilai sub kriteria untuk yang lain sama yaitu 5, 4, 3, 2, 1 maka nilai Eigen Vector Normalization juga sama, jadi tidak perlu dihitung. Langkah berikutnya adalah proses perangkingan berdasarkan nilai akademik dan Eigen Vector Normalization serta sub kriteria, seperti pada Tabel 21.

\begin{tabular}{|c|c|c|c|c|}
\hline \multirow{2}{*}{ Mahasiswa } & \multicolumn{3}{|c|}{ Kriteria } & \multirow{2}{*}{ Hasil } \\
\hline & $\mathrm{C} 1$ & $\mathrm{C} 2$ & $\mathrm{C} 3$ & \\
\hline 1 & 5 & 5 & 1 & 0,355 \\
\hline 2 & 4 & 5 & 1 & 0,253 \\
\hline 3 & 4 & 5 & 1 & 0,253 \\
\hline 4 & 4 & 5 & 1 & 0,253 \\
\hline 5 & 4 & 5 & 1 & 0,253 \\
\hline 6 & 4 & 4 & 1 & 0,231 \\
\hline 7 & 4 & 3 & 1 & 0,210 \\
\hline 8 & 4 & 5 & 1 & 0,253 \\
\hline 9 & 4 & 5 & 1 & 0,253 \\
\hline 10 & 3 & 3 & 2 & 0,126 \\
\hline 11 & 4 & 5 & 1 & 0,253 \\
\hline 12 & 4 & 5 & 1 & 0,253 \\
\hline 13 & 4 & 3 & 1 & 0,210 \\
\hline 14 & 4 & 3 & 1 & 0,210 \\
\hline 15 & 4 & 3 & 1 & 0,210 \\
\hline 16 & 3 & 2 & 2 & 0,117 \\
\hline 17 & 5 & 5 & 1 & 0,355 \\
\hline 18 & 3 & 5 & 1 & 0,157 \\
\hline 19 & 4 & 5 & 1 & 0,253 \\
\hline 20 & 4 & 5 & 1 & 0,253 \\
\hline
\end{tabular}

TABEL XXI

PERANGKINGAN BERDASARKAN NILAI AKADEMIK DAN EVN KRITERIA DAN SUB KRITERIA
Langkah berikutnya proses perangkingan berdasarkan nilai non akademik dan eigen vektor normalisasi serta sub kriteria, seperti pada Tabel 22.

\begin{tabular}{|c|c|c|c|c|}
\hline \multirow{2}{*}{ Mahasiswa } & \multicolumn{3}{|c|}{ Kriteria } & \multirow{2}{*}{ Hasil } \\
\hline & $\mathrm{C} 4$ & $\mathrm{C} 5$ & C6 & \\
\hline 1 & 5 & 1 & 1 & 0,205 \\
\hline 2 & 2 & 1 & 1 & 0,144 \\
\hline 3 & 5 & 1 & 1 & 0,205 \\
\hline 4 & 2 & 1 & 1 & 0,144 \\
\hline 5 & 3 & 1 & 1 & 0,154 \\
\hline 6 & 5 & 1 & 2 & 0,234 \\
\hline 7 & 4 & 1 & 2 & 0,208 \\
\hline 8 & 2 & 2 & 1 & 0,102 \\
\hline 9 & 2 & 1 & 1 & 0,144 \\
\hline 10 & 4 & 1 & 2 & 0,208 \\
\hline 11 & 2 & 2 & 1 & 0,102 \\
\hline 12 & 5 & 1 & 1 & 0,124 \\
\hline 13 & 2 & 1 & 1 & 0,144 \\
\hline 14 & 3 & 1 & 2 & 0,183 \\
\hline 15 & 5 & 5 & 1 & 0,096 \\
\hline 16 & 3 & 1 & 1 & 0,154 \\
\hline 17 & 2 & 1 & 1 & 0,144 \\
\hline 18 & 2 & 2 & 1 & 0,102 \\
\hline 19 & 2 & 2 & 1 & 0,102 \\
\hline 20 & 2 & 2 & 1 & 0,102 \\
\hline
\end{tabular}

TABEL XXII

PERANGKINGAN BERDASARKAN NILAI NON AKADEMIK DAN EVN KRITERIA DAN SUB KRITERIA

\subsection{Akademik dan Non Akademik}

Langkah pertama adalah membuat matrik perbandingan kriteria dengan nilai yang telah diinputkan seperti pada Tabel 23.

TABEL XXIII

PERBANDINGAN BERPASANGAN ALTERNATIF AKADEMIK DAN NON AKADEMIK

\begin{tabular}{|l|c|c|}
\hline \multicolumn{1}{|c|}{ Ket } & Akademik & Non Akademik \\
\hline Akademik & 1 & 5 \\
\hline Non Akademik & $1 / 5$ & 1 \\
\hline
\end{tabular}

Langkah kedua mengubah nilai perbandingan berpasangan menjadi bentuk desimal dan menjumlahkan setiap kolom sel pada kolom matriks dibagi dengan jumlah kolom pada setiap selnya, seperti pada Tabel 24 
TABELXXIV

NILAI DESIMAL

\begin{tabular}{|l|c|c|}
\hline \multicolumn{1}{|c|}{ Non Akademis } & Akademik & Non Akademik \\
\hline Akademik & 1,000 & 5,000 \\
\hline Non Akademik & 0,200 & 1,000 \\
\hline Total & 1,200 & 6,000 \\
\hline
\end{tabular}

Membagi elemen tiap kolom dengan total jumlah kolom bersangkutan, seperti pada Tabel 25 .

TABEL XXV

HASIL PEMBAGIAN NILAI ELEMENT DENGAN

TOTAL JUMLAH KOLOM

\begin{tabular}{|l|c|c|}
\hline \multicolumn{1}{|c|}{ Non Akademis } & Akademik & Non Akademik \\
\hline Akademik & 0,833 & 0,833 \\
\hline Non Akademik & 0,167 & 0,167 \\
\hline
\end{tabular}

Menghitung nilai Eigen Vector Normalization (EVN) dengan cara menjumlahkan tiap baris kemudian dibagi dengen jumlah kriteria, seperti pada Tabel 26.

TABEL XXVI
NILAI EVN
\begin{tabular}{|l|c|c|}
\hline \multicolumn{1}{|c|}{ Non Akademis } & Jumlah & EVN \\
\hline Akademik & 1,667 & 0,833 \\
\hline Non Akademik & 0,333 & 0,167 \\
\hline
\end{tabular}

Langkah ketiga mencari lamda sesuai rumus yang diawali dengan perhitungan nilai eigen maksimum.:

$\lambda$ maks $=(1,200 * 0,833)+(6,000 * 0,167)$

$\lambda$ maks $=2,000$

Langkah keempat menghitung konsistensi indeks (CI) dengan hasil lamda dikurang dengan banyaknya kriteria dibagi jumlah kriteria dengan rumus, sebagai berikut:

$$
C I=\frac{\lambda m a k s-n}{\mathrm{n}-1}
$$

$\mathrm{CI}=(\lambda$ maks-n $) /(\mathrm{n}-1)$

$\mathrm{CI}=(2,000-2) /(2-1)$

$\mathrm{CI}=0,000$

Langkah kelima mencari konsistensi rasio (CR). Karena jumlah kriteria ada 3 maka nilai indeks random konsistensi (RI) adalah 0. Dapat dihitung dengan rumus :

$$
C R=\frac{C I}{R I}
$$

$\mathrm{CR}=\mathrm{CI} / \mathrm{RI}$

$\mathrm{CR}=0,000 / 0$

$\mathrm{CR}=0,0$

Nilai CR $<0,1$ maka preferensi pembobotan adalah konsisten
Langkah berikutnya adalah proses perangkingan berdasarkan nila akademik, non akademik dan Eigen Vector Normalization, seperti pada Tabel 27.

TABEL XXVII

PERANGKINGAN BERDASARKAN NILAI AKADEMIK DAN NON

\begin{tabular}{|c|c|c|c|}
\hline Data & Akademik & $\begin{array}{c}\text { Non } \\
\text { Akademik } \\
\end{array}$ & Hasil \\
\hline 1 & 0,367 & 0,205 & 0,340 \\
\hline 26 & 0,367 & 0,165 & 0,334 \\
\hline 17 & 0,367 & 0,144 & 0,330 \\
\hline 25 & 0,355 & 0,165 & 0,324 \\
\hline 21 & 0,355 & 0,136 & 0,319 \\
\hline 29 & 0,355 & 0,136 & 0,319 \\
\hline 30 & 0,355 & 0,136 & 0,319 \\
\hline 2 & 0,265 & 0,144 & 0,245 \\
\hline 8 & 0,265 & 0,102 & 0,238 \\
\hline 11 & 0,265 & 0,102 & 0,238 \\
\hline 3 & 0,243 & 0,205 & 0,236 \\
\hline 5 & 0,243 & 0,154 & 0,228 \\
\hline 4 & 0,243 & 0,144 & 0,226 \\
\hline 9 & 0,243 & 0,144 & 0,226 \\
\hline 6 & 0,222 & 0,234 & 0,224 \\
\hline 12 & 0,243 & 0,124 & 0,223 \\
\hline 19 & 0,243 & 0,102 & 0,219 \\
\hline 20 & 0,243 & 0,102 & 0,219 \\
\hline 15 & 0,243 & 0,096 & 0,218 \\
\hline 14 & 0,222 & 0,183 & 0,215 \\
\hline 7 & 0,213 & 0,208 & 0,212 \\
\hline 13 & 0,222 & 0,144 & 0,209 \\
\hline 28 & 0,157 & 0,165 & 0,159 \\
\hline 10 & 0,114 & 0,208 & 0,129 \\
\hline 27 & 0,126 & 0,136 & 0,127 \\
\hline 18 & 0,126 & 0,102 & 0,122 \\
\hline 24 & 0,110 & 0,173 & 0,121 \\
\hline 16 & 0,114 & 0,154 & 0,120 \\
\hline 22 & 0,098 & 0,208 & 0,116 \\
\hline 23 & 0,058 & 0,070 & 0,060 \\
\hline
\end{tabular}
AKADEMIK

Jadi, dari hasil pembahasan dan perhitungan yang dilakukan dari awal sampai proses terakhir, maka mahasiswa yang membutuhkan pengawasan secara ekstra dalam proses pembelajaran yaitu ada 8 mahasiswa yang memiliki nilai terendah dari mahasiswa yang lain, dapat dilihat pada tabel diatas.. 


\section{KESIMPULAN}

Metode Analitycal Hierarchy Process (AHP) berhasil diterapkan pada sistem pendukung keputusan dalam penentuan mahasiswa yang diprioritaskan untuk pengawasan dalam proses pembelajaran. Hasil dari perhitungan menggunakan metode AHP dalam penentuan bobot prioritas mahasiswa yang membutuhkan pengawasan dalam pembelajaran sangat tergantung pada pemberian nilai terhadap kriteria dan sub kriteria.

\section{REFRENSI}

[1] T. L. Saaty., "Pengambilan Keputusan Bagi Para Pemimpin, Proses Hirarki Analitik untuk Pengambilan Keputusan dalam Situasi yang Kompleks”. Pustaka Binama Pressindo. 1993.

[2] Kursini,. "Konsep dan Aplikasi Sistem Pendukung Keputusan. Yogyakarta". Penerbit Andi. 2007

[3] Haryansyah, E. Novianto, E. T. Putri., "Analisa Pengawasan Studi Mahasiswa Menggunakan Metode Analytic Hierarchy Process (AHP) dan Clustering K-Means Sebagai Bahan Evaluasi Akademik". STMIK AMIKOM, ISSN : 2302-3805, 2014

[4] A. T. Kurniawan, M. Munir., "Analytic Hierarchy Process (AHP) untuk penentuan Rangking Penggunaan Lahan". Journal Of Research and Technology, Vol. 3 No.1. 2017

[5] S. K. Gusti., "Analisa dan Penerapan Metode AHP dan Promethee untuk Menentukan Guru Berprestasi”., Jurnal IRMSI, Vol 4 No. 1. 2018

[6] B. Sinaga, H. M. Zebua., "Sistem Pendukung Keputusan Siswa Berprestasi Menggunakan Metode Analytic Hierarchy Process (AHP) pada SMK Singosari Delitua"., Jurnal Mantik Penusa, Vol 16 No.2., 2014

[7] T. Mufizar, D. S. Anwar, R. K. Dewi., "Pemilihan Calon Penerima Bantuan Siswa Miskin Menggunakan Metode Analytical Hierarchy Process"., Citec Journal, Vol. 4 No. 12016

[8] R. M. Simanjorang, H. D. Hutahaean, H. T. Sihotang., "Sistem Pendukung Keputusan Penentuan Penerima Bahan Pangan Bersubsidi untuk Keluarga Miskin dengan Metode AHP pada Kantor Keluarahan Mangga". Journal Of Informatic Pelita Nusantara, Vol. 2 No. 1. 2017

[9] R. Ahamad., " Penggunaan Sistem Pendukung Keputusan dengan Menggunakan Metode Analytical Hirarchy Process (AHP) dalam Menyeleksi Kelayakan Penerimaan Beasiswa”, Metik Jurnal, Vol 2 No. 1.2018

[10] W. H. Am, E. Kumalasari, Rr. Y. Rachmawati., “ Penerapan Metode Analytical Hierarchy Process (AHP) pada Sistem Pendukung Keputusan Pemilihan Mahasiswa Berprestasi Menggunakan Framework Laravel., Jurnal SCRIPT, Vol 3. No.1. 2015 